\title{
Tumor Necrosis Factor- $\alpha$ Allele Lymphotoxin- $\alpha+250$ Is Associated with the Presence and Severity of Placental Inflammation among Preterm Births
}

S. NADYA J. KAZZI, SUZANNE M. JACQUES, FAISAL QURESHI, MICHAEL W. QUASNEY, U. OLIVIA KIM, AND IRINA A. BUHIMSCHI

Division of Neonatology, Departments of Pediatrics [S.N.J.K., U.O.K.], Pathology [S.M.J., F.Q.], and Obstetrics and Gynecology [I.A.B.], Wayne State University, Detroit, MI 48201, U.S.A.; and Division of Critical Care[M.W.Q.], Department of Pediatrics, Le Bonheur Children's Medical Center, University of

Tennessee, Memphis, TN 38103, U.S.A.

\begin{abstract}
Histologic inflammation of placenta has been associated with increased risk for bronchopulmonary dysplasia and periventricular leukomalacia among preterm infants. Tumor necrosis factor- $\alpha$ $(\mathrm{TNF}-\alpha)$ plays a central role in the regulation of inflammation. Some alleles of TNF (LT- $\alpha+250$, TNF- $\alpha-308$, and TNF$\alpha-238$ ) have been associated with susceptibility and/or severity of many diseases characterized by inflammation and/or involving the immune system. To determine whether alleles of TNF- $\alpha$ affect the risk and/or the severity of chorioamnionitis, we examined the placentas of 101 preterm births (birth weight $\leq 1250 \mathrm{~g}$ ) for the presence of inflammation. Maternal and fetal chorioamnionitis (MCA and FCA, respectively) were graded for severity and staged for location of inflammatory infiltrate. Analysis for TNF- $\alpha$ alleles was done using PCR-restriction fragment length polymorphism technique on DNA extracted from infants' whole blood. MCA and FCA were seen in 45 and 38 placentas, respectively ( $p=0.64)$. Genotypes of TNF- $\alpha-308$ did not affect the development or the severity of placental inflammation. However,
\end{abstract}

\section{ABSTRACT}

the AA genotype of LT- $\alpha+250$ occurred more often when MCA and FCA were present compared with placentas without inflammation ( $p=0.016$ and $p=0.007$, respectively). The GA genotype of TNF- $\alpha-238$ was more common in placentas with severe MCA than with mild MCA $(p=0.015)$. The number of A alleles of LT $-\alpha+250(\mathrm{GG}=0, \mathrm{GA}=1, \mathrm{AA}=2)$ correlated directly and significantly with grades and stages of MCA and FCA $(p<0.05)$. The AA genotype of LT- $\alpha+250$ is associated with the development of chorioamnionitis among preterm births. The A allele of LT- $\alpha+250$ seems to worsen the degree of placental inflammation. (Pediatr Res 56: 94-98, 2004)

FCA, fetal chorioamnionitis

LT, lymphotoxin

MCA, maternal chorioamnionitis

PMN, polymorphonuclear leukocyte

TNF- $\alpha$, tumor necrosis factor- $\alpha$
Chorioamnionitis has long been recognized as an important cause of neonatal morbidity and mortality (1). It has been associated with preterm birth, preterm premature rupture of the fetal membranes, increased risk of neonatal sepsis, and death (2). Chorioamnionitis complicates up to $45 \%$ of all premature births with an incidence inversely proportional to gestational age $(3,4)$. There is strong evidence to support a possible role for chorioamnionitis in neonatal encephalopathy and development of cerebral palsy among term infants (5-8). Preterm infants who are exposed to chorioamnionitis are at increased

Received August 14, 2003; accepted March 1, 2004.

Correspondence: S. Nadya J. Kazzi, M.D., M.P.H., Division of Neonatal-Perinatal Medicine, Department of Pediatrics, Hutzel Hospital, 4707 St. Antoine, Detroit, MI 48201, U.S.A.; e-mail: nkazzi@med.wayne.edu

DOI: 10.1203/01.PDR.0000130474.12948.A4 risk of periventricular leukomalacia, cerebral palsy $(7,9)$, and chronic lung disease $(10-13)$. Tumor necrosis factor- $\alpha$ $(\mathrm{TNF}-\alpha)$ is an inducible cytokine and an important regulator of the inflammatory response with a broad range of proinflammatory and immunostimulatory actions $(14,15)$. TNF- $\alpha$ is released by activated monocytes and/or macrophages early during an inflammatory reaction, and it induces the release of many other proinflammatory mediators such as IL-1, IL-6, and itself. Dysregulation of an inflammatory response resulting from an overproduction of proinflammatory cytokines may result in an exaggerated, uncontrolled inflammatory reaction; interfere with initiation of repair processes; and induce autoinjury with underlying tissue damage (16). Overproduction of TNF- $\alpha$ has been reported to occur in the presence of certain alleles within the regulatory region of the gene (17). Suscep- 
tibility and severity of many infectious diseases such as sepsis, cerebral malaria, leishmaniasis, and Chlamydia as well as autoimmune diseases such as multiple sclerosis, rheumatoid arthritis, systemic lupus erythematosus, and Crohn's disease are thought to have a genetic basis and have been linked to polymorphisms in the TNF- $\alpha$ gene regulatory region (18).

The TNF gene is located within the MHC on chromosome 6, along with two related genes encoding lymphotoxin- $\alpha$ (LT- $\alpha$ ) and lymphotoxin- $\beta$ (LT- $\beta$ ) (19). Lymphotoxin- $\alpha$, also referred to as TNF- $\beta$, has actions similar to those of TNF- $\alpha$, but its expression is more restricted.

A number of genetic polymorphisms in the TNF- $\alpha$ regulatory region resulting in the substitution of the nucleotide adenine (A) for guanine (G) at positions LT- $\alpha+250$, TNF$\alpha-238$ and TNF- $\alpha-308$ have been associated with higher levels of transcription of TNF- $\alpha$ gene $(17,20,21)$. In this report, we examined whether the presence of the A allele of TNF$\alpha-238$, TNF- $\alpha-308$, and LT- $\alpha+250$ among preterm infants affected the risk of developing chorioamnionitis and the severity of placental inflammation.

\section{METHODS}

Infants were recruited from the neonatal intensive care nursery at Hutzel Hospital (Detroit, MI, U.S.A.). All infants who had a birth weight $\leq 1250 \mathrm{~g}$ were eligible for the study. After informed consent was obtained, $0.5 \mathrm{~mL}$ of whole blood was drawn either from an indwelling arterial or venous umbilical line or by venipuncture. DNA was extracted using the Genomic DNA purification Kit (Promega, Madison, WI, U.S.A.). Genotypic analysis for TNF- $\alpha$ polymorphic sites was performed using a PCR-restriction fragment length polymorphism technique, as previously described (22-24).

All placentas were processed in a standard manner. This included taking three full-thickness sections from the placental disc, three sections from the maternal surface, two sections of the cord, and a membrane roll. All sections were stained with hematoxylin and eosin. Maternal (MCA) and fetal (FCA) chorioamnionitis, when present, were graded on a scale of $0-2$ on the basis of the severity and staged on a scale of $0-3$ on the basis of the extent of the acute inflammatory infiltrate as manifested by polymorphonuclear leukocytes (PMNs).

MCA was graded as follows: grade 0, no inflammation; grade 1 , not severe; and grade 2 , severe inflammation defined as chorionic microabscesses in membranes and/or under the chorionic plate or a continuous band of confluent PMNs occupying more than one half of subchorionic fibrin or one revolution of the membrane roll. MCA staging included stage 0 , no inflammation; stage 1, few PMNs in subchorionic plate fibrin and/or membranous chorionic trophoblast layer; stage 2, more than a few PMNs in the chorionic plate and/or chorionic connective tissue, amnion, or deciduus of membranes; and stage 3 (necrotizing chorioamnionitis) with karyorrhectic neutrophils, thickened amnionic eosinophilic basement membranes, and focal amnionic epithelial degeneration.

FCA was graded as follows: grade 0 , no inflammation; grade 1 , not severe; and grade 2, severe with many PMNs in chorionic surface vessels with attenuation and/or degeneration of vascular smooth muscle. FCA was staged as follows: stage 0 , no inflammation; stage 1 , PMNs in the wall of any chorionic surface vessel or the umbilical vein; stage 2, PMNs in one or both umbilical arteries; and stage 3 (necrotizing funisitis) with PMNs, cellular debris, mineralization, and/or neovascularization arranged in concentric bands, rings, or halo-like distribution around cord vessels. Two pathologists (S.M.J. and F.Q.) examined the placentas and graded and staged the inflammation without knowledge of the distribution of TNF- $\alpha$ alleles among infants.

Demographic variables and medical data were collected on all participants. Clinical chorioamnionitis was diagnosed in the presence of a temperature elevation of $37.8^{\circ} \mathrm{C}$ or higher and two or more of the following criteria: uterine tenderness, foul-smelling amniotic fluid, fetal tachycardia (fetal heart rate $>160$ ), and maternal leukocyte count $>15,000$ cells $/ \mathrm{mm}^{3}$ in the absence of another source of infection (25). The diagnosis of prolonged premature rupture of the fetal membranes was made when duration of membrane rupture was $\geq 18 \mathrm{~h}$. The study was approved by the Institutional Review Board at Wayne State University School of Medicine.

Statistical analysis. $\chi^{2}$ test was used to compare the genotypic frequencies and other categorical variables. Continuous variables were compared using $t$ test. Kendall's tau_b correlation was used to examine the relationship between grades and stages of placental inflammation with genotypes of TNF- $\alpha$. A $p \leq 0.05$ was set for all analyses.

\section{RESULTS}

A total of 101 preterm infants were recruited. MCA was detected in $45 \%$ of placentas and FCA in $38 \%$ of placentas ( $p$ $=0.64$ ). There was no difference in maternal age, gravidity and parity, racial distribution, use of antenatal steroids, and infants' birth weight among infants with MCA and those without MCA $(p<0.05$; Table 1$)$. Mothers of infants with MCA were more likely to have a diagnosis of clinical chorioamnionitis, to have prolonged rupture of fetal membranes of $\geq 18 \mathrm{~h}$, to have received antenatal antibiotics, and to deliver more immature infants than mothers of infants without MCA $(p<0.05$; Table 1). The genotypic distribution of alleles of TNF- $\alpha-238$ and TNF- $\alpha-308$ was comparable among infants with and without MCA (Table 2). However, the AA genotype of LT- $\alpha+250$ occurred significantly

Table 1. Mother and infant characteristics

\begin{tabular}{lcc}
\hline & $\begin{array}{c}\text { MCA present } \\
(n=45)\end{array}$ & $\begin{array}{c}\text { No MCA } \\
(n=56)\end{array}$ \\
\hline Maternal age (y) & $27 \pm 7$ & $26 \pm 7$ \\
Gravidity/parity & $4 \pm 3 / 2 \pm 2$ & $3 \pm 2 / 2 \pm 2$ \\
Black/white/Hispanic & $13 / 32 / 0$ & $10 / 42 / 4$ \\
Antenatal steroids & $36(80 \%)$ & $44(79 \%)$ \\
Clinical chorioamnionitis & $15(33 \%)^{*}$ & $3(5 \%)^{*}$ \\
PROM $\geq 18$ h & $17(38 \%)^{*}$ & $4(7 \%)^{*}$ \\
Antibiotic therapy & $34(76 \%)^{*}$ & $16(29 \%)^{*}$ \\
Birth weight (g) & $866 \pm 201$ & $930 \pm 220$ \\
Gestational age (wk) & $26 \pm 4^{*}$ & $28 \pm 2^{*}$ \\
\hline
\end{tabular}

Values are mean $( \pm \mathrm{SD})$ or number (percentage of patients). PROM, premature rupture of membranes.

* $T$ test or $\chi^{2}$ test, $p=0.001$. 
Table 2. Genotypes of TNF and maternal placental inflammation*

\begin{tabular}{|c|c|c|c|c|c|c|c|c|c|}
\hline & \multicolumn{3}{|c|}{$\mathrm{LT}-\alpha+250$} & \multicolumn{3}{|c|}{ TNF- $\alpha-238$} & \multicolumn{3}{|c|}{ TNF- $\alpha-308$} \\
\hline & AA & GA & GG & AA & GA & GG & AA & GA & GG \\
\hline No MCA $(n=56)$ & $25 \%$ & $43 \%$ & $32 \%$ & $5 \%$ & $4 \%$ & $91 \%$ & $5 \%$ & $21 \%$ & $74 \%$ \\
\hline $\operatorname{MCA}(n=45)$ & $47 \%$ & $42 \%$ & $11 \%$ & - & $11 \%$ & $89 \%$ & $2 \%$ & $18 \%$ & $80 \%$ \\
\hline$p$ value & & 0.016 & & & 0.107 & & & 0.626 & \\
\hline Grade 1 MCA $(n=23)$ & $52 \%$ & $35 \%$ & $13 \%$ & - & - & $100 \%$ & - & $22 \%$ & $78 \%$ \\
\hline Grade 2 MCA $(n=22)$ & $41 \%$ & $50 \%$ & $9 \%$ & - & $23 \%$ & $77 \%$ & $4 \%$ & $14 \%$ & $82 \%$ \\
\hline$p$ value & & 0.583 & & & 0.015 & & & 0.477 & \\
\hline Frequency of A allele & A & & $\mathrm{G}$ & A & & $\mathrm{G}$ & A & & $\mathrm{G}$ \\
\hline No MCA $(n=56)$ & 0.46 & & 0.54 & 0.07 & & 0.93 & 0.16 & & 0.84 \\
\hline $\operatorname{MCA}(n=45)$ & 0.68 & & 0.32 & 0.06 & & 0.94 & 0.11 & & 0.89 \\
\hline$p$ value & & 0.004 & & & 0.866 & & & 0.418 & \\
\hline
\end{tabular}

$* \chi^{2}$ test.

Table 3. Genotypes of TNF and fetal placental inflammation*

\begin{tabular}{|c|c|c|c|c|c|c|c|c|c|}
\hline & \multicolumn{3}{|c|}{$\mathrm{LT}-\alpha+250$} & \multicolumn{3}{|c|}{$\mathrm{TNF}-\alpha-238$} & \multicolumn{3}{|c|}{$\mathrm{TNF}-\alpha-308$} \\
\hline & AA & GA & GG & $\mathrm{AA}$ & GA & GG & AA & GA & GG \\
\hline No FCA $(n=63)$ & $25 \%$ & $43 \%$ & $32 \%$ & $5 \%$ & $3 \%$ & $92 \%$ & $5 \%$ & $22 \%$ & $73 \%$ \\
\hline $\mathrm{FCA}(n=38)$ & $50 \%$ & $42 \%$ & $8 \%$ & - & $13 \%$ & $87 \%$ & $2 \%$ & $16 \%$ & $82 \%$ \\
\hline$p$ value & & 0.007 & & & 0.071 & & & 0.608 & \\
\hline Grade 1 FCA $(n=36)$ & $50 \%$ & $42 \%$ & $8 \%$ & - & $11 \%$ & $89 \%$ & $3 \%$ & $14 \%$ & $83 \%$ \\
\hline Grade 2 FCA $(n=2)$ & - & $50 \%$ & $50 \%$ & - & $50 \%$ & $50 \%$ & - & $50 \%$ & $50 \%$ \\
\hline$p$ value & & 0.906 & & & 0.113 & & & 0.391 & \\
\hline
\end{tabular}

$* \chi^{2}$ test.

more often among infants with MCA compared with infants without MCA ( $p=0.016$; Table 2). Among infants with MCA, the GA genotype of TNF- $\alpha-238$ occurred significantly more often among infants with severe MCA (grade 2) compared with infants with less severe MCA (grade $1 ; p=0.015$; Table 2). The frequency of the A allele of LT $-\alpha+250$ was significantly higher among infants with MCA than infants without MCA $(p=0.004$; Table 2). Similarly, the AA genotype of LT- $\alpha+250$ was more likely to be present among infants with FCA than infants without FCA $(p=0.007$; Table 3$)$. Genotypes of TNF- $\alpha-238$ and TNF- $\alpha-308$ were comparable among infants with and without FCA $(p>0.05$; Table 3$)$. There was no difference in the genotypic distribution of all three alleles of TNF- $\alpha$ among infants with mild (grade 1) and severe (grade 2) FCA ( $p>0.05$; Table 3). There were significant positive correlations between the number of A alleles of LT- $\alpha+250(\mathrm{GG}=0, \mathrm{GA}=1$, and $\mathrm{AA}=2)$ and grades of MCA as well as grades of FCA (Table 4). Similarly, there were significant direct correlations between the number of $\mathrm{A}$ alleles of LT $-\alpha+250$ and stages of MCA and FCA (Table 4). The number of A alleles of TNF- $\alpha-238$ did not correlate with grades of MCA $(p>0.05)$.

The genotypic distribution of alleles of LT- $\alpha+250$, TNF$\alpha-238$ and TNF- $\alpha-308$ was comparable among male $(n=$ $48)$ and female $(n=53)$ infants $(p>0.05)$, as well as among infants of variable racial backgrounds (Table 5). The genotypic distribution of LT $-\alpha+250$ among our infants was similar to that reported in adults (Table 6).

\section{DISCUSSION}

In this study, we examined the role of alleles in the regulatory region of TNF gene, specifically LT- $\alpha+250$, TNF$\alpha-238$, and TNF- $\alpha-308$, on the susceptibility and severity of
Table 4. Severity of placental inflammation and $L T-\alpha+250$ genotype*

\begin{tabular}{lccllc}
\hline & \multicolumn{2}{c}{ MCA } & & \multicolumn{2}{c}{ FCA } \\
\cline { 2 - 3 } \cline { 5 - 6 } & $R$ & $p$ value & & $R$ & $p$ value \\
\hline Grades of inflammation 0-2 & 0.236 & 0.013 & & 0.274 & 0.006 \\
Stages of inflammation $0-3$ & 0.253 & 0.007 & & 0.254 & 0.008 \\
\hline
\end{tabular}

* Kendall's tau_b.

placental inflammation among preterm births. We found that the presence of the AA genotype of LT- $\alpha+250$ correlated significantly and directly with the susceptibility to develop MCA as well as FCA. Furthermore, the severity of placental inflammation correlated positively and significantly with the number of A alleles of LT $-\alpha+250$. The GA genotype of TNF- $\alpha-238$ occurred more often among infants with severe MCA (grade 2) compared with infants with less severe MCA (grade 1). However, we found no significant correlation between the number of A alleles of TNF- $\alpha-238$ and placental inflammation.

The possible role of the A allele of LT- $\alpha+250$ in human disease states has been reported by other investigators. Quasney et al. (24) found an increased frequency of the AA genotype of LT $-\alpha+250$ among white children with Kawasaki disease compared with healthy control subjects. The AA genotype of LT $-\alpha+250$ was associated with more severe psoriasis (26) and higher rate of mortality among children with bacteremia (27) and septic adults (22). Adult patients who had community-acquired pneumonia and were carriers of the AA LT $-\alpha+250$ genotype were more likely to develop septic shock (28). Patients with multiple sclerosis were more likely to be carriers of the AA genotype of LT- $\alpha+250$ compared with control subjects (29). 
Table 5. Racial distribution of TNF- $\alpha$ genotypes*

\begin{tabular}{|c|c|c|c|c|c|c|c|c|c|}
\hline & \multicolumn{3}{|c|}{$\mathrm{LT}-\alpha+250$} & \multicolumn{3}{|c|}{$\mathrm{TNF}-\alpha-238$} & \multicolumn{3}{|c|}{$\mathrm{TNF}-\alpha-308$} \\
\hline & AA & GA & GG & AA & GA & GG & AA & GA & GG \\
\hline White $(n=21)$ & $48 \%$ & $43 \%$ & $9 \%$ & - & - & $100 \%$ & $5 \%$ & $14 \%$ & $81 \%$ \\
\hline Black $(n=76)$ & $29 \%$ & $43 \%$ & $28 \%$ & $4 \%$ & $10 \%$ & $86 \%$ & $4 \%$ & $26 \%$ & $70 \%$ \\
\hline Hispanic $(n=4)$ & $25 \%$ & $75 \%$ & - & - & - & $100 \%$ & - & - & $100 \%$ \\
\hline
\end{tabular}

* $\chi^{2}$ test, $p>0.05$.

Table 6. Genotypic distribution of $L T-\alpha+250$ in premature infants compared with reported frequency in adults*

\begin{tabular}{lccc}
\hline & AA & GA & GG \\
\hline Premature infants in study & $32 \%$ & $45 \%$ & $23 \%$ \\
Waterer et al. $(28)$ & $30 \%$ & $48 \%$ & $22 \%$ \\
Yende et al. (45) & $39 \%$ & $42 \%$ & $19 \%$ \\
\hline
\end{tabular}

* $\chi^{2}$ test, $p>0.05$.

Reports on the possible role of TNF- $\alpha-308$ and TNF$\alpha-238$ on susceptibility and severity of diseases involving the innate immune system have yielded conflicting results. The A allele of TNF- $\alpha-308$ occurred more often among children who had Kawasaki disease and developed coronary artery abnormalities (24). Carriage of the A allele of TNF- $\alpha-308$ was associated with worse outcome among patients with cerebral malaria (30), leishmaniasis (31), and severe sepsis (32) but had no effect on the susceptibility to or severity of rheumatoid arthritis (33), multiple sclerosis (34), or Crohn disease (35). Similarly, the A allele of TNF- $\alpha-238$ was associated with severe silicosis (36) but was absent among patients with severe rheumatoid arthritis $(33,37)$.

Although our data may suggest that carriage of the A allele of TNF- $\alpha-238$ might be protective for histologic chorioamnionitis and may play a role in the severity of placental inflammation, the skewed distribution of genotypes of TNF$\alpha-238$ makes interpretation of this data difficult. Other investigators have suggested a possible protective role for the A allele of TNF- $\alpha-238$ in disease conditions involving inflammation and/or the immune system (33,37-39). Perhaps a multicenter trial with a much larger sample size might shed more light on the functional significance of the A allele of TNF$\alpha-238$ in susceptibility and severity of chorioamnionitis.

We did not measure cord blood levels of TNF- $\alpha$ in our infants. Several other investigators had reported elevated levels of TNF- $\alpha$ in the presence of TNF- $\alpha-308$, TNF- $\alpha-238$, and LT- $\alpha+250$ alleles $(22,40,41)$. However, several intrapartum events, such as fetal distress, maternal fever, and/or intrapartum administration of antibiotics, may affect cord blood TNF- $\alpha$ levels (42-44).

So how could this association between the AA genotype of LT- $\alpha+250$ and increased susceptibility to and severity of MCA and FCA be explained? Most diseases are the result of an interaction between an individual's genetic makeup, the environment, and the process that initiates injury. Disease is rarely regulated by the activity of a single gene. Thus, a more likely explanation for our observation is that the AA LT- $\alpha+250$ genotype represents a marker for a cluster of co-regulated genes that are involved in the initiation and regulation of the inflammatory response. The TNF locus is located within the
MHC, a dense cluster of highly polymorphic genes that determine an individual's immune response $(45,46)$. The region encodes several proteins that are involved in inflammation, stress responses, and host defense. Furthermore, by affecting levels of transcription of the TNF- $\alpha$ gene, the A allele of LT- $\alpha+250$ may precipitate a disequilibrium between the proand anti-inflammatory cytokines, promoting the development and progression of placental inflammation.

Because placental inflammation is commonly found among preterm births $(45 \%)$, we entertained the possibility that the occurrence of the A allele/AA genotype of LT- $\alpha+250$ may just be a marker of prematurity. However, the finding of a similar genotypic distribution of LT- $\alpha+250$ among our preterm infants and that reported among adults $(28,47)$ refuted that hypothesis.

To our knowledge, this is the first report to examine the role of genotypes of TNF on histologically documented placental inflammation among preterm infants. Simhan et al. (48) explored the relationship between carriage of the A allele of TNF- $\alpha-308$ and clinical chorioamnionitis. They found a higher rate of clinical chorioamnionitis (24.4\%) among pregnant women at term (37-42 wk gestation) who were carriers of the A allele of TNF- $\alpha-308$ compared with noncarriers (7.4\%). Clinical criteria for the diagnosis of chorioamnionitis are somewhat insensitive in detecting cases with histologic placental inflammation (49). Our findings were based on histologic diagnosis of placental inflammation. In our study, only $33 \%$ of patients with histologic evidence of chorioamnionitis had a diagnosis of clinical chorioamnionitis.

\section{CONCLUSION}

In summary, our data demonstrate that the AA genotype of LT $-\alpha+250$ increases the susceptibility to chorioamnionitis among preterm births. The presence of the A allele of LT$\alpha+250$ worsens the severity of placental inflammation.

\section{REFERENCES}

1. Gibbs RS, Romero R, Hillier SL, Eschenbach DA, Sweet RL 1992 A review of premature birth and subclinical infection. Am J Obstet Gynecol 166:1515-1528

2. Elimian A, Verma U, Beneck D, Cipriano R, Visintainer P, Tejani N 2000 Histologic chorioamnionitis, antenatal steroids, and perinatal outcomes. Obstet Gynecol 96:333336

3. Romero R, Mazor K, Wu YK, Sirtori M, Oyarzun E, Mitchell MD, Hobbins JC 1988 Infection in the pathogenesis of preterm labor. Semin Perinatol 12:262-279

4. Goncalves LF, Chaiworapongsa T, Romero R 2002 Intrauterine infection and prematurity. Ment Retard Dev Disabil Res Rev 8:3-13

5. Grether JK, Nelson KB 1997 Maternal infection and cerebral palsy in infants of normal birth weight. JAMA 278:207-211

6. Nelson KB, Dambrosia JM, Grether JK, Phillips TM 1998 Neonatal cytokines and coagulation factors in children with cerebral palsy. Ann Neurol 44:665-675

7. Wu YW, Colford JM Jr 2000 Chorioamnionitis as a risk factor for cerebral palsy: a meta-analysis. JAMA 284:1417-1424

8. Willoughby RE Jr, Nelson KB 2002 Chorioamnionitis and brain injury. Clin Perinatol 29:603-621 
9. Yoon BH, Jun JK, Romero R, Park KH, Gomez R, Choi JH, Kim IO 1997 Amniotic fluid inflammatory cytokines (interleukin-6, interleukin-1 beta, and tumor necrosis factor alpha), neonatal brain white matter lesions, and cerebral palsy. Am J Obstet Gynecol 177:19-26

10. Watterberg KL, Demers LM, Scott SM, Murphy S 1996 Chorioamnionitis and early lung inflammation in infants in whom bronchopulmonary dysplasia develops. Pediatrics 97:210-215

11. Yoon BH, Romero R, Jun JK, Park KH, Park JD, Ghezzi F, Kim BI 1997 Amniotic fluid cytokines (interleukin-6, tumor necrosis factor-alpha, interleukin-1 beta, and interleukin-8) and the risk for the development of bronchopulmonary dysplasia. Am J Obstet Gynecol 177:825-830

12. Lyon A 2000 Chronic lung disease of prematurity. The role of intra-uterine infection. Eur J Pediatr 159:798-802

13. Jobe AH, Ikegami M 2001 Antenatal infection/inflammation and postnatal lung maturation and injury. Respir Res 2:27-32

14. Eigler A, Sinha B, Hartmann G, Endres S. 1997 Taming TNF: strategies to restrain this proinflammatory cytokine. Immunol Today 18:487-492

15. Männel DN, Echtenacher B 2000 TNF in the inflammatory response. Chem Immunol $74: 141-161$

16. Downey GP, Granton JT 1997 Mechanisms of acute lung injury. Curr Opin Pulm Med $3: 234-241$

17. Allen RD 1999 Polymorphism of the human TNF- $\alpha$ promoter-random variation or functional diversity? Mol Immunol 36:1017-1027

18. Zhang M, Tracey KJ 1998 Tumor necrosis factor. In: Thomson AW (ed) The Cytokine Handbook. Academic Press, London, pp 517-548

19. Gruen JR, Weissman SM 1997 Evolving views of the major histocompatibility complex. Blood 90:4252-4265

20. Kroeger KM, Carville KS, Abraham LJ 1997 The -308 tumor necrosis factor- $\alpha$ promoter polymorphism effects transcription. Mol Immunol 34:391-399

21. Warzocha K, Ribeiro P, Bienvenu J, Roy P, Charlot C, Rigal D, Coiffier B, Salles G 1998 Genetic polymorphisms in the tumor necrosis factor locus influence nonHodgkin's lymphoma outcome. Blood 91:3574-3581

22. Stuber F, Petersen M, Bokelmann F, Schade U 1996 A genomic polymorphism within the tumor necrosis factor locus influences plasma tumor necrosis factor concentrations and outcome of patients with severe sepsis. Crit Care Med 24:381-384

23. Wilson AG, di Giovine FS, Blakemore A, Duff GW 1992 Single base polymorphism in the human tumor necrosis factor alpha (TNF alpha) gene detectable by $\mathrm{Nco}$ restriction of PCR product. Hum Mol Genet 1:353

24. Quasney MW, Bronstein DE, Cantor RM, Zhang Q, Stroupe C, Shike H, Bastian JF, Matsubara T, Fujiwara M, Akimoto K, Newburger JW, Burns JC 2001 Increased frequency of alleles associated with elevated tumor necrosis factor- $\alpha$ levels in children with Kawasaki disease. Pediatr Res 49:686-690

25. Pacora P, Chaiworapongsa T, Maymon E, Kim YM, Gomez R, Yoon BH, Ghezzi F, Berry SM, Qureshi F, Jacques SM, Kim JC, Kadar N, Romero R 2002 Funisitis and chorionic vasculitis: the histological counterpart of the fetal inflammatory response syndrome. J Matern Fetal Neonatal Med 11:18-25

26. Balding J, Kane D, Livingstone W, Mynett-Johnson L, Bresnihan G, Smith O, FitzGerald O 2003 Cytokine gene polymorphisms: association with psoriatic arthritis susceptibility and severity. Arthritis Rheum 48:1408-1413

27. McArthur JA, Zhang Q, Quasney MW 2002 Association between the A/A genotype at the lymphotoxin- $\alpha+250$ site and increased mortality in children with positive blood cultures. Pediatr Crit Care Med 3:341-344

28. Waterer GW, Quasney MW, Cantor RM, Wunderink RG 2001 Septic shock and respiratory failure in community-acquired pneumonia have different TNF polymorphism associations. Am J Respir Crit Care Med 163:1599-1604

29. Fernandes Filho JA, Vedeler CA, Myhr KM, Nyland H, Pandey JP 2002 TNF-alpha and -beta gene polymorphisms in multiple sclerosis: a highly significant role for determinants in the first intron of the TNF-beta gene. Autoimmunity 35:377-380

30. McGuire W, Hill AV, Allsopp CE, Greenwood BM, Kwiatkowski D 1994 Variation in the TNF- $\alpha$ promoter region associated with susceptibility to cerebral malaria Nature 371:508-510

31. Cabrera M, Shaw MA, Sharples C, Williams H, Castes M, Convit J, Blackwell JM 1995 Polymorphism in tumor necrosis factor genes associated with mucocutaneous leishmaniasis. J Exp Med 182:1259-1264
32. Mira JP, Cariou A, Grall F, Delclaux C, Losser MR, Heshmati F, Cheval C, Monch M, Teboul JL, Riche F, Leleu G, Arbibe L, Mignon A, Delpech M, Dhainaut JF 1999 Association of TNF2, a TNF-alpha promoter polymorphism, with septic shock susceptibility and mortality: a multicenter study. JAMA 282:561-568

33. Brinkman BM, Huizinga TW, Kurban SS, van der Velde EA, Schreuder GM, Hazes JM, Breedveld FC, Verweij CL 1997 Tumour necrosis factor $\alpha$ gene polymorphism in rheumatoid arthritis: association with susceptibility to, or severity of, disease? Br J Rheumatol 36:516-521

34. Wingerchuk D, Liu Q, Sobell J, Sommer S, Weinshenker BG 1997 A populationbased case-control study of the tumor necrosis factor alpha-308 polymorphism in multiple sclerosis. Neurology 49:626-628

35. Louis E, Vermeire S, Rutgeerts P, De Vos M, Van Gossum A, Pescatore P, Fiasse R, Pelckmans P, Reynaert H, D'Haens G, Malaise M, Belaiche J 2002 A positive response to infliximab in Crohn disease: association with a higher systemic inflammation before treatment but not with -308 TNF gene polymorphism. Scand J Gastroenterol 37:818-824

36. Yucesoy B, Vallyathan V, Landsittel DP, Sharp DS, Weston A, Burleson GR, Simeonova P, McKinstry M, Luster MI 2001 Association of tumor necrosis factor- $\alpha$ and interleukin-1 gene polymorphisms with silicosis. Toxicol Appl Pharmacol $172: 75-82$

37. Fabris M, Di PE, D’Elia A, Damante G, Sinigaglia L, Ferraccioli G 2002 Tumor necrosis factor-alpha gene polymorphism in severe and mild-moderate rheumatoid arthritis. J Rheumatol 29:29-33

38. Jang WH, Yang YI, Yea SS, Lee YJ, Chun JH, Kim HI, Kim MS, Paik KH 2001 The -238 tumor necrosis factor- $\alpha$ promoter polymorphism is associated with decreased susceptibility to cancers. Cancer Lett 166:41-46

39. Hernandez-Pacheco G, Flores-Dominguez C, Rodriguez-Pérez JM, Pérez-Hernández N, Fragoso JM, Saul A, Alvarez-León E, Granados J, Reyes PA, Vargas-Alarcón G 2003 Tumor necrosis factor-alpha promoter polymorphisms in Mexican patients with rheumatic heart disease. J Autoimmun 21:59-63

40. Bouma G, Crusius JB, Oudkerk Pool M, Kolkman JJ, von Blomberg BM, Kostense PJ, Giphart MJ, Schreuder GM, Meuwissen SG, Pena AS 1996 Secretion of tumour necrosis factor alpha and lymphotoxin alpha in relation to polymorphism in the TNF genes and HLA-DR alleles. Relevance for inflammatory bowel disease. Scand J Immunol 4:456-463

41. Louis E, Franchimont D, Piron A, Gevaert Y, Schaaf-Lafontaine N, Roland S, Mahieu P, Malaise M, De Groote D, Louis R, Belaiche J 1998 Tumour necrosis factor (TNF) gene polymorphism influences TNF-alpha production in lipopolysaccharide (LPS)stimulated whole blood cell culture in healthy humans. Clin Exp Immunol 113:401406

42. Jokic M, Guillois B, Cauquelin B, Giroux JD, Bessis JL, Morello R, Levy G, Ballet JJ 2000 Fetal distress increases interleukin-6 and interleukin- 8 and decreases tumour necrosis factor-alpha cord blood levels in noninfected full-term neonates. BJOG 107:420-425

43. Netea MG, Kullberg BJ, Van der Meer JW 2000 Circulating cytokines as mediators of fever. Clin Infect Dis 31:S178-S184

44. Holzheimer RG 2001 Antibiotic induced endotoxin release and clinical sepsis: a review. J Chemother 13:159-172

45. Gruen JR, Weissman SM 1997 Evolving views of the major histocompatibility complex. Blood 90:4252-4265

46. Beck S, Trowsdale J 2000 The human major histocompatibility complex: lessons from the DNA sequence. Annu Rev Genomics Hum Genet 1:117-137

47. Simhan HN, Krohn MA, Zeevi A, Daftary A, Harger G, Caritis SN 2003 Tumor necrosis factor- $\alpha$ promoter gene polymorphism -308 and chorioamnionitis. Obstet Gynecol 102:162-166

48. Yende S, Quasney MW, Tolley E, Zhang Q, Wunderink RG 2003 Association of tumor necrosis factor gene polymorphisms and prolonged mechanical ventilation after coronary artery bypass surgery. Crit Care Med 31:133-140

49. Smulian JC, Shen-Schwarz S, Vintzileos AM, Lake MF, Ananth CV 1999 Clinical chorioamnionitis and histologic placental inflammation. Obstet Gynecol 94:10001005 